Alicia Salomone

\title{
Metapoesía y autoficción en la escritura poética de Begoña Ugalde: Poemas sobre mi normalidad (2018) y La fiesta vacía (2019)
}

\section{Introducción}

Este trabajo se propone analizar la discursividad metapoética en la obra de la escritora chilena Begoña Ugalde (1984). Por metapoesía entenderé la reflexión en la identidad de este género y en la praxis poética en la misma poesía, ${ }^{1}$ lo que se articula en la escritura de Ugalde con una exploración en la subjetividad lírica y su puesta en escena en el poema. ${ }^{2}$ Seguiré las huellas de esa discursividad a través del análisis de imágenes y discursos presentes en los enunciados poemáticos, evidenciando los recursos autoficcionales y metapoéticos en el corpus poético en estudio.

La producción escritural de Begoña Ugalde abarca diversos géneros, pero es en la poesía donde ella establece su identidad literaria principal. Esta parte de su obra se inicia en 2009 con la publicación del poemario El cielo de los animales, al que siguen Thriller (2011), La Virgen de las Antenas (2012), Lunares (2016), y los dos poemarios que son objeto de este ensayo: Poemas sobre mi normalidad (2018) y La fiesta vacía (2019). El primero de ellos recrea un espacio íntimo donde la hablante lírica propone una representación autoficcional, dibujándose a sí misma como un sujeto inserto en una red de afectos primordiales. Allí se hacen presentes abuelos, padres, parejas, hijos y vecinos, a partir de los cuales delimita su lugar en el mundo y su identidad literaria. El segundo poemario, por su parte, escenifica a una hablante poética que se desplaza por el espacio público adoptando distintos ropajes y máscaras, apareciendo alternativamente como una serpiente eléctrica, un cisne, una maga, o una mujer sabia que sana las miserias que descubre en sus recorridos por la urbe.

1 Laura Scarano: «Escribo que escribo: de la metapoesía a las autopoéticas». In: Tropelías: Revista de Teoría de la Literatura y Literatura Comparada 2 (2017), p. 133-152.

2 Víctor Zonana citado en Laura Scarano: «Escribo», p. 40.

Note: Trabajo realizado en el marco del Proyecto Fondecyt 1118033.

Alicia Salomone, Universidad de Chile

๖ Open Access. ( 2021 Alicia Salomone, published by De Gruyter. (c) BY-NC-ND This work is licensed under the Creative Commons Attribution-NonCommercial-NoDerivatives 4.0 International License.

https://doi.org/10.1515/9783110736274-013 
Más allá de sus diferencias temáticas, escénicas y de disposición en las hablantes líricas, ambos libros comparten una inflexión metapoética que liga la reflexión sobre la praxis poética con la capacidad transformadora de la subjetividad lírica, sea en el espacio íntimo como en el mundo del afuera. Por otra parte, se trata de una subjetividad que siempre deja manifiesto su anclaje en un cuerpo y en las identidades que adopta, haciendo que, desde la materialidad significante de la «voz producida en el poema», se pueda acceder a «los ecos de la voz productora». ${ }^{3}$

\section{Metapoesía y autoficción poética}

En un estudio reciente, Laura Scarano revisa un conjunto de definiciones sobre la metaficción y, en particular, sobre la metapoesía, en la teoría crítica contemporánea. Desde Roland Barthes - «Escribo: esto es el primer grado del lenguaje. Escribo que escribo: es el segundo grado» ${ }^{4}-$, analiza la problemática del metalenguaje y la metaliteratura, haciéndose cargo de una dilatada tradición crítica que abarca tanto el ámbito sajón como el hispánico. Por esta vía, llega a la metapoesía, rescatando propuestas que, como las de José Antonio Pérez Bowie, ${ }^{5}$ describen al poema metapoético como aquel que espectaculariza su configuración, evidenciando su manufactura y estrategias. ${ }^{6}$ Asimismo, Scarano recoge conceptualizaciones de otros autores como Guillermo Carnero y Leopoldo Sánchez Torre. Del primero, rescata la relación que establece entre el texto, el sujeto productor y el receptor cuando afirma que la «metapoesía es el discurso poético cuyo asunto es el hecho mismo de escribir poesía y la relación entre autor, texto y público». ${ }^{7}$ De Sánchez Torre, retoma, por un lado, la idea de que la metapoesía es un discurso mediante el cual los poetas explicitan sus presupuestos teóricos en el poema, «como si quisieran añadir un plus de significación indispensable a sus

3 Laura Scarano: «Poesía y nombre de autor: entre el imaginario autobiográfico y la autoficción». In: CELEHIS: Revista del Centro de Letras Hispanoamericanas 22 (2011), p. 232.

4 Roland Barthes (1978) cit. en Laura Scarano: «Escribo», p. 133.

5 José Antonio Pérez Bowie: «Para una tipología de los procedimientos metaficcionales en la lírica contemporánea». In: Tropelías 3 (1992), p. 91-114; José Antonio Pérez Bowie: «Sobre lírica y autorreferencia (algunos ejemplos de la poesía española contemporánea)». In: J. M. Pérez Gago (ed.): Semiótica y modernidad II, p. 237-247. A Coruña: Universidad de A Coruña 1994.

6 Laura Scarano: «Escribo», p. 136.

7 Guillermo Carnero: «Precedentes de la poesía social de la postguerra española en la anteguerra y guerra civil». In: Las armas abisinias: Ensayos sobre literatura y arte del siglo XX. Barcelona: Anthropos 1989, cit. en Laura Scarano: «Escribo», p. 136. 
programas de escritura». ${ }^{8} \mathrm{Y}$, por otro lado, la visión de que la metapoesía supone «una estrategia de acercamiento al receptor», cuyo fin es el reconocimiento del «yo objetivado, «autobiográfico», desde el que se enuncia el poema». ${ }^{9}$

Junto con Gianni Vattimo, ${ }^{10}$ Scarano ${ }^{11}$ también subraya el rol central que han tenido las artes poéticas en el panorama artístico del siglo XX, a través de las cuales los creadores producen representaciones de sí en el poema, poniendo la mirada en la labor escritural y los vínculos que los ligan con generaciones, tradiciones poéticas, sociedades y mercados. Por otra parte, en diálogo con Víctor Zonana y María Clara Lucifora, Scarano destaca que estas teorizaciones les permiten a los creadores observar la propia obra desde un distanciamiento crítico. Ello posibilita abrir diálogos con el campo literario y referirse al estilo, el lenguaje, el género y la relación obra-mundo, delimitando un lugar propio dentro de un contexto, proyecto o tradición. Para Lucifora, ${ }^{12}$ comentando a Zonana, las poéticas pueden servir para delimitar las condiciones que el creador propone para la recepción e interpretación de su obra. Por su parte, el propio Zonana explicita la conexión entre las poéticas de autor y las representaciones del yo, dando cuenta del «carácter metaficcional de «la imagen o mitología del yo, que sirve para entender el sentido otorgado al acto creador»». ${ }^{13}$

Scarano había analizado estas mismas problemáticas en un estudio anterior, señalando que la autoficción poética, es decir, las autorrepresentaciones que los poetas exponen en su escritura, son los mecanismos que materializan la «articulación de 〈quien dice yo〉 en el discurso poético». ${ }^{14}$ Estas operatorias dan cuenta de una identidad «ambigua», sustentada en un pacto autobiográfico entre productor y lector, que procede sin «clausurar su operatividad ficcional ni la referencial». ${ }^{15}$ De esta forma, la autoficción ancla en la autobiografía, pero fusiona borrosamente ambos espacios en el plano del lenguaje, generando que «el yo vivido y el inventado» experimenten una suerte de equiparación. ${ }^{16}$ Así,

8 Laura Scarano: «Escribo», p. 137.

9 Leopoldo Sánchez Torre: La poesía en el espejo del poema. La práctica metapoética en la poesía española del siglo XX. Oviedo: Universidad de Oviedo 2010, cit. en Laura Scarano: «Escribo», p. 137. 10 Gianni Vattimo: Poesía y ontología. Valencia: Universidad de Valencia 1993.

11 Laura Scarano: «Escribo», p. 138.

12 María Clara Lucifora: «Las autopoéticas como máscaras». In: RECIAL: Revista del Centro de Investigaciones de la Facultad de Filosofía y Humanidades, Áreas Letras 11 (2017), s. p. https:// dialnet.unirioja.es/revista/23617/V/8 [Consultado el 25 de junio 2020].

13 Víctor Zonana: Poéticas de autor en la literatura argentina (desde 1950), vol. I. Buenos Aires: Corregidor 2007, p. 31.

14 Laura Scarano: «Poesía y nombre», p. 219.

15 Ibid., p. 226.

16 Ibid., p. 228. 
para Scarano, el poema autoficcional sugiere una «lectura vacilante» ${ }^{17}$ que, si bien no desestima la dimensión ficcional, invita al lector a una interpretación autobiográfica. Se trata, entonces, de una praxis de «lenguaje sobre el lenguaje, literatura dentro de la literatura, ficción sobre la ficción, repliegue especular». ${ }^{18}$ Una labor que subraya el carácter autorreflexivo, autorreferencial, del poema, pero, al mismo tiempo, lo abre, no sin tensión, a su relación con las configuraciones culturales y con las identidades de género, raza, clase o nacionalidad que están en la base de la subjetividad que enuncia el poema.

\section{Desplazamiento identitarios y metapoesía en la escritura de mujeres chilenas de los años 2000}

Las dos décadas que abarca el nuevo milenio han sido fértiles para poesía de mujeres en Chile. Es el tiempo en el que se inscribe la escritura de Begoña Ugalde, junto a la de poetas como Gladys González, Paula Ilabaca, Ivonne Coñuecar, Julieta Marchand, Daniela Catrileo, Florencia Smiths, Natalia Figueroa, Carolina Pezoa, Ashle Ozuljevic Subaique y Rocío Cano, entre varias otras. En 1992, a solo dos años del retorno a la democracia tras la dictadura de Augusto Pinochet (1973-1990), la poeta Elvira Hernández todavía ironizaba sobre cómo las escritoras debían buscar cobijo bajo ciertos paraguas protectores - la literatura de mujeres o la crítica feminista, por ejemplo- mientras tenían que precaverse, al mismo tiempo, de no caer en viejos esencialismos:

Algunos hombres poetas hablan fríamente de practicar una «escritura femenina» como una manera de decirnos que están con los nuevos tiempos, mientras a muchas de nosotras nos persigue el terror de estas reproduciendo solapadamente la «escritura del otro». ${ }^{19}$

A comienzos de 2010, el espacio de la literatura de mujeres chilenas no solo aparecía ya como un espacio más consolidado, sino que se veía fortalecido por el desarrollo de redes entre las escritoras y por las intervenciones colectivas que ellas comenzaban a realizar en un campo cultural más abierto. Entre esas iniciativas, destacan la creación de editoriales, la organización de encuentros literarios y críticos, la organización de ferias del libro alternativas a las oficiales y la creación

17 Ibid., p. 229-230.

18 Ibid., p. 231-232.

19 Elvira Hernández: «Contemporaneidad de la poesía escrita por mujeres en la poesía chilena». In: Simpson: Sociedad de Escritores de Chile 7 (1992), p. 109. 
de instancias gremiales de discusión y articulación. Por otra parte, en el lapso de esta década, muchas de estas escritoras y poetas también se vincularon con el emergente movimiento de mujeres y feministas que eclosionaría con fuerza en Chile entre 2018 y 2020.

La mayoría de las poetas de los 2000 cuenta con una formación académica que era menos frecuente en las generaciones previas, $y$, además, varias de ellas se han radicado fuera de Chile, o han pasado períodos en el extranjero, sin por ello perder el contacto con el lugar de origen. Ello posibilitó que la geografía poética chilena se expandiera más allá del territorio, adoptando un perfil transterritorial, transcultural y transidentitario, en tanto esta poesía borronea las fronteras nacionales, establece diálogos (más o menos tensionados) entre la cultura propia y la de los países de acogida, y, si bien no reniega de sus raíces, las trastoca, hibridiza y redefine en términos estéticos y políticos. La propia distancia frente al espacio originario, por otra parte, posibilita que las subjetividades líricas delineadas en las obras puedan examinar la relación con Chile desde una mirada descentrada, desde el lugar de enunciación que cada hablante habilita al saberse habitante de un espacio ajeno o al que no pertenece del todo.

Hay que destacar, por otra parte, que la mayor visibilidad de la cohorte poética de mujeres de los 2000 debe explicarse a la luz de una genealogía que se ha configurado ya como una tradición reconocible. Me refiero al ímpetu creador que eclosiona en Chile en los años 1980 con la palabra desgarrada por la violencia dictatorial en poetas como Elvira Hernández, Soledad Fariña, Carmen Berenguer y Verónica Zondek. ${ }^{20}$ Un impulso que, en la postdictadura, toma nuevos rumbos estéticos, pasando, entre otras líneas, por la poética poblada de hijas huérfanas en medio de paisajes en ruinas de Alejandra del Río, Antonia Torres y Verónica Jiménez; ${ }^{21}$ y por la poesía de hondura autorreflexiva de poetas como Nadia Prado ${ }^{22}$ o Malú

20 Naín Nómez: «Poesía de mujeres en Chile: Voces del simulacro entre la dictadura y la transición». In: Milena Rodríguez Gutiérrez (ed.): Casa en la que nunca he sido extraña. Las poetas hispanoamericanas: identidades, feminismos, poéticas (Siglos XIX-XXI), p. 91-102. New York: Peter Lang 2017; Bárbara Fernández Melleda: Neoliberalism and its Discontents. Three Decades of Chilean Women's Poetry [PhD Dissertation]. Edimburgo: The University of Edimburgh 2019. https:// era.ed.ac.uk/bitstream/handle/1842/35852/Fernandez2019.pdf?sequence=1\&isAllowed=y [Consultado el 25 de abril 2020].

21 Magda Sepúlveda: «El territorio y el testigo en la poesía chilena de la Transición». In: Estudios filológicos 45 (2010), p. 79-92.

22 Julieta Marchant Rivera: El ser o su intermedio: el desmontaje del yo en la poesía de Nadia Prado [Tesis para optar al grado de Magíster en Literatura]. Santiago de Chile: Universidad de Chile 2013. http://repositorio.uchile.cl/handle/2250/115168 [Consultado el 25 de junio 2020]. 
Urriola. ${ }^{23}$ Otro hito ineludible desde los años 1990 en adelante son las poéticas de mujeres mapuche que, desde el conflicto entre hablas, identidades y memorias, exploran en lenguajes con que reponer territorios, cuerpos y deseos suprimidos, como sucede con la poesía de Adriana Paredes Pinda, Roxana Miranda Rupailaf y Maribel Mora Curriao, entre muchas otras. ${ }^{24}$

Portadora de estas herencias, la poesía actual de mujeres teje alianzas con las voces precedentes y las contemporáneas, evidenciando recurrencias temáticas y expresivas, y dando forma a una política de la escritura que acoge crecientemente al feminismo como un discurso que facilita y articula la confluencia. En este sentido, no puede extrañar que las subjetividades líricas instalen figuras de mujeres autoconscientes, que deambulan por múltiples espacios y producen un descentramiento del yo lírico desde el tránsito del yo hacia un sujeto colectivo: nosotras. Por otra parte, si bien estas subjetividades no dejan de estar afectadas por el trauma vivido en Chile durante la pasada dictadura, de cuya memoria quedan huellas explícitas en la poesía, sus voces se inscriben en un escenario menos clausurado, donde ya no pueden ser simplemente acalladas. Los movimientos sociales de los años 2000 -estudiantiles, indígenas, ecológicos, de trabajadores y sobre todo feministas - quebraron la inmovilidad de los noventa, abriendo la escena sociocultural a la expresión de nuevas demandas y sujetos. Por su parte, la revuelta social iniciada en octubre de 2019 posibilitó su convergencia, haciendo confluir las demandas feministas y de disidencia sexual, que venían denunciando la opresión patriarcal, la violencia sexista y el orden heteronormativo, con críticas decoloniales, antirracistas, ecologistas y con otras posiciones que cuestionan la dominancia del neoliberalismo extractivista.

Situada en la encrucijada de desafíos locales y globales, buena parte de la poesía de mujeres chilenas de la presente década amplía el ángulo de visión y resitúa su lugar de habla, poniéndose a distancia de las dimensiones opresivas del Estado-nación chileno y su oficialidad cultural. Desde esa instalación, esta poesía escenifica sujetos situados entre y a través de territorios, lenguas y culturas, que deconstruyen la dicotomía público-privado, que habitan identidades no hegemónicas, y que exponen el deseo erótico en la escritura, interrogando al lenguaje y la praxis poética que los configura como tales. Por otra parte, a la luz de esta evolución, no puede extrañar que en este corpus se manifieste un claro

23 Edson Faúndez: «Geografía de la nada. La poesía de Malú Urriola». In: Taller de Letras 54 (2014), p. 39-56.

24 Maribel Mora Curriao y Fernanda Moraga (eds.): Kümedungun/Kümewirin. Antología poética de mujeres mapuche (siglos XX-XXI). Santiago de Chile: LOM 2010; Soledad Falabella, Graciela Huinao y Roxana Miranda Rupailaf (eds.): Hilando en la memoria. Epu rupa. 14 mujeres mapuche. Santiago de Chile: Cuarto Propio 2009. 
clivaje metapoético, desde el cual se interroga al lenguaje poético y a las voces que lo habitan y crean. Me refiero a la poesía que Ivonne Coñuecar produce entre la Patagonia chilena y las urbes argentinas, escenificando «subjetividades fronterizas», ${ }^{25}$ en claro conflicto entre emociones opresivas y puntos de fuga; a las hibridaciones lingüísticas entre castellano y mapudungún, en la escritura dolida de Daniela Catrileo; ${ }^{26}$ al vagabundeo marginal y autoconsciente del yo lírico en la poesía de Gladys González; ${ }^{27}$ y, entre otras, a la subjetividad crítica y en movimiento de la poesía que Begoña Ugalde produce en Barcelona.

\section{Poemas sobre mi normalidad de Begoña Ugalde: poesía y transformación subjetiva en el espacio íntimo}

En el texto que prologa el libro Poemas sobre mi normalidad (2018) de Begoña Ugalde, Flavia Company afirma que el agregado del posesivo «mi» a la palabra «normalidad» en el título del poemario trasporta este término a un lugar «intransferible hasta el momento de verse convertido en poesía». ${ }^{28}$ La subjetividad lírica instala su voz en un mundo propio, en el doble sentido de autónomo y apropiado, y así entrega a sus lectores «el misterio de ciertos instantes», antiguas memorias, «vacilaciones y certezas». ${ }^{29}$

Desde ese reino personal, el poemario invita a poner atención en la configuración del yo lírico y su conexión con la poesía, lo que se articula desde una trama de afectos que ligan a la hablante del poemario, hacia atrás y hacia adelante, con abuelos, padres, parejas, hijos. No obstante, desde otra perspectiva, el uso del posesivo también podría leerse como un acento irónico que ilumina una distancia entre lo que es habitual y asumido como natural o incluso como norma o regla (RAE), condiciones sobre las cuales raramente se reflexiona, y un

25 Fernanda Moraga: «Catabática: cartografía de subjetividades fronterizas». In: Literatura y Lingüística 26 (2012), p. 47-59.

26 Luongo, Gilda: «Guerra Florida de Daniela Catrileo: «Perfume fragante de la memoriamadreselva〉 o «esta danza es por nosotras»». In: Biblioteca fragmentada (2019). http://www.bibliotecafragmentada.org/guerra-florida-de-daniela-catrileo/ [Consultado el 25 de abril].

27 Martina Bortignon: «Fotos y voces en la ciudad. La marginalidad en la poesía chilena del 2000 desde una perspectiva intermedial». In: Literatura y Lingüística 22 (2015), p. 159-178.

28 Flavia Company: «Vivir desde lugar propio y ajeno». In: Begoña Ugalde: Poemas sobre mi normalidad. Santiago: Aerea-Carmenere 2018, p. 7.

29 Ibid., p. 7. 
yo que observa su espacio y, en ese gesto, lo evalúa y resignifica. La inserción del posesivo, entonces, devela una subjetividad lírica que altera el orden normal de las cosas, el orden doméstico, en este caso, para sugerir que el ámbito reproductivo, lejos de ser solo un espacio opresivo, abre a la hablante posibilidades creativas. De hecho, es en ese lugar, y en medio de esa red amorosa que la rodea y nutre, donde ella encuentra el sustento para enunciar su voz y construir una identidad literaria. Se trata de un camino que emprenderá a través de su poesía, procurando sumar una marca propia a la cadena de relatos y formas que, con sabiduría, sus ancestros supieron legarle y que ella intentará remodelar y prolongar. Dice en el poema «Carta»:

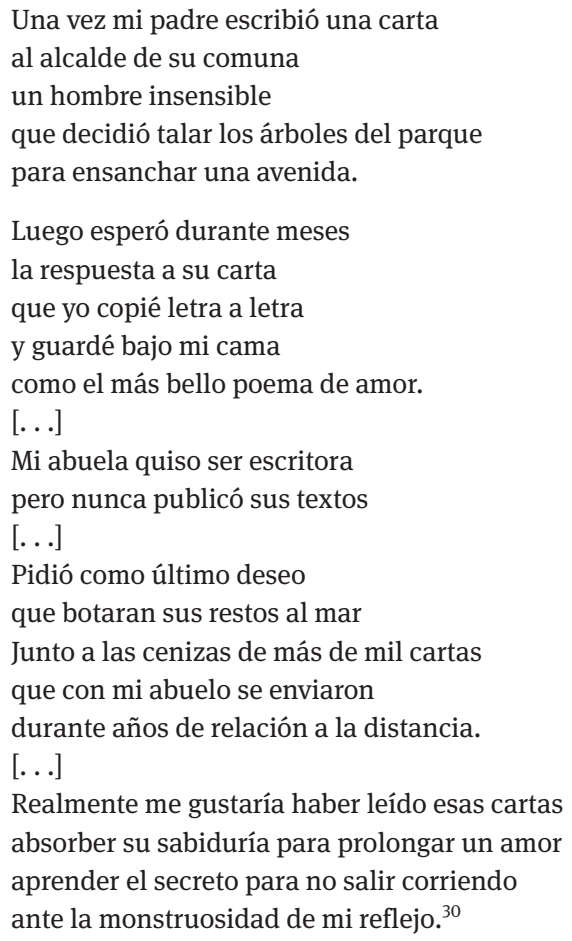

Desde los lazos genéticos de la genealogía familiar a las afiliaciones electivas de la vida adulta, la escritura poética es el medio expresivo que la subjetividad lírica encuentra para lidiar con las glorias y miserias de la memoria y los mandatos del pasado, sin someterse pasivamente a ellos. Por otra parte, es la escritura la

30 Begoña Ugalde: Poemas sobre mi normalidad. Santiago de Chile: RIL Editores/Aerea-Carménère 2018, p. 18-22. 
que también permite hacer frente al agobio cotidiano, que siempre amenaza con instalar el desasosiego desde la intrascendencia de esas rutinas domésticas que anticipan la quietud de la muerte. Así, es la poesía el espacio donde esos temores y obsesiones pueden mirarse a la distancia y repensarse. Es lo que ocurre en el poema «Sistema solar», por ejemplo, donde la hablante lírica recuerda un sueño y una escena en la que desea tomar las témperas del hijo para cubrir con sus versos las paredes de la casa, mientras se observa a sí misma intentando vanamente cumplir con las labores de alimentación familiar y responder a las múltiples demandas filiales:

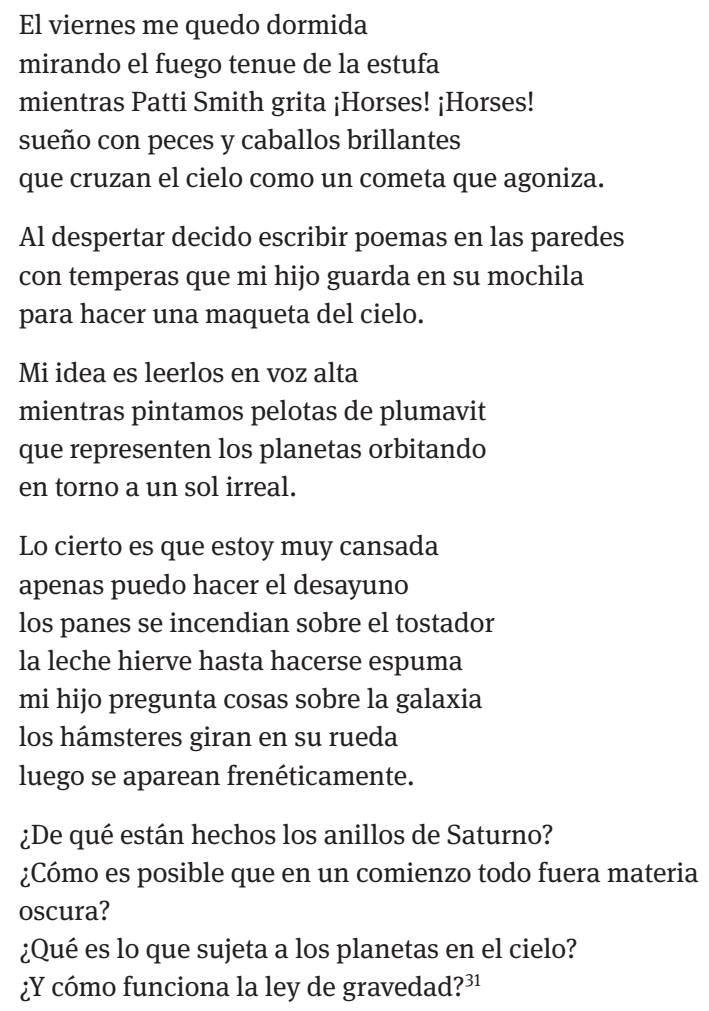

Más allá de las tensiones que la domesticidad impone a las posibilidades vitales de la hablante lírica, es la poesía la que, finalmente, puede producir en ella una radical transformación identitaria, como se narra en el poema «Ropa seca», en el que describe una extraña escena ocurrida en el patio de su vecindad. En ese

31 Ibid., p. 38. 
rincón inesperado, silencioso y estrecho, donde apenas logra entrar un poco del sol necesario para el secado de la ropa, la hablante es llevada más allá del umbral de la alienación doméstica a través de los juegos sonoros que produce una niña con su boca. De ese modo, logra mutar el rol de madre-esposa abnegada por el de una sibila que, trasladada a un espacio trascendente y dotada de poderes proféticos, logra descifrar los indicios de un mundo en agonía:

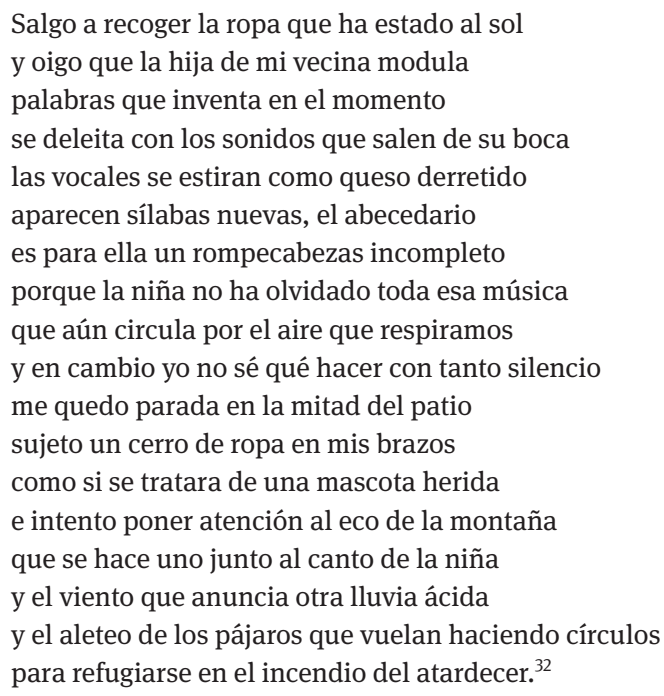

\section{La fiesta vacía: la poesía como crítica e ideación de nuevas realidades}

A diferencia del escenario íntimo en que se inscribe la hablante lírica de Poemas sobre mi normalidad, en La fiesta vacía, un largo poema compuesto de múltiples fragmentos sin título, se pone en escena a una mujer que recorre la ciudad de Barcelona en medio de una romería interminable. A primera vista, ella parece una flâneuse contemporánea, aparentemente deslumbrada por el derroche de colores, cuerpos y fuegos de artificio que estallan en el cielo. Sin embargo, se nombra a sí misma como «una serpiente eléctrica / que vaga sola / entre corales deshabitados / y cables rotos». ${ }^{33}$ Una imagen en la que resuenan los ecos de la

32 Ibid., p. 31.

33 Begoña Ugalde y Gema Polanco: La fiesta vacía. Barcelona: TEJE 2019, p. 34. 
caminata solitaria de Teresa - alter ego de la poeta Elvira Hernández- por una urbe plagada de contradicciones - «Robótica y Mendicante ${ }^{34}-$, en la apertura de Santiago Waria. $^{35}$

Al igual que la figura del poemario de Hernández, la hablante de La fiesta vacía también es una otra en el escenario que describe. Proviene de un mundo distante, cuyos colores y ritmos musicales, y los jirones de su historia trágica, han quedado adheridos a su memoria: la imagen del Palacio de la Moneda en llamas en 1973.

En estas coordenadas imprecisas, perdí

las llaves de lo que alguna vez fue mi casa

el sentido del humor y casi el del olfato

pero no olvidé mis coreografías andinas

estrategias de guerra florida

ni las instrucciones para construir palacios inflamables

que cobran importancia en su incendio. ${ }^{36}$

No obstante, ese lugar ha quedado atrás en el tiempo y el espacio, y hoy resulta para ella un territorio definitivamente inaccesible:

¿Puedes recordar el camino de vuelta?

¿Los nombres con que llamabas a tus hermanas? ${ }^{37}$

En este país extranjero, la palabra y la escritura cobran para la hablante lírica un valor inusitado como articuladores de la continuidad del yo y sus vínculos, pero también como un poder del que puede apropiarse para recapitular su vida y reflexionar en torno a sus nuevas experiencias:

Lo que importa es este léxico de cercanía y continuidad

lo que dices mirando la nada que silba en la azotea

o a esas golondrinas que insisten en hacer figuras a contraluz

cada atardecer como si fueran manifiestos lanzados al aire

que invitan a tomarse todo y aprender a amarnos de otra forma..$^{38}$

En La fiesta vacía son recurrentes las imágenes referidas a la escritura, con sus múltiples formas, variaciones, soportes y posibilidades. Pero, además, esa carac-

34 Elvira Hernández: Los trabajos y los días: Antología. Santiago de Chile: Lumen 2016, p. 123.

35 «Anda Sola / mira para atrás / solo tú quedas / en el camino [..] Sodomas y Gorgonas están por delante / a solo 6 kilómetros / son tu ciudadela / tu podio [.. .] Anda Sola Teresa vieja» (Elvira Hernández: Los trabajos, p. 115).

36 Begoña Ugalde y Gema Polanco: La fiesta, p. 42.

37 Ibid., p. 17.

38 Ibid., p. 39. 
terística es enfatizada desde un elemento constructivo que subraya la inclinación metapoética del poemario mediante su puesta en abismo con la materialidad de otros géneros y discursos. Me refiero, en particular, al diálogo intermedial que entabla la escritura de Ugalde con las fotografías de la española Gema Polanco. ${ }^{39}$ En su despliegue a lo largo del libro, esas imágenes visuales configuran una narrativa paralela que acompaña a la que produce la voz lírica, si bien ofreciendo un contrapunto no mimético. De esta manera, ambos relatos plasman miradas e instalaciones diferentes, convergiendo en ciertos nodos, pero dibujando trayectorias disímiles. Por otra parte, ese doble registro material y significante posibilita a la hablante analizar sus recursos y elaborar sus propias percepciones, iluminando, desde la mediación de la fotografía, aquello que el discurso desvanece: lo que se difumina, lo que se mueve y huye de la palabra articulada, lo que se descubre de soslayo, «lo inacabado e incompleto, e incluso lo ominoso e innombrable». ${ }^{40}$

Algunas imágenes visuales de Polanco se centran en la corporalidad femenina, representándola como una fuente de poder y creatividad, tal como sucede con la fotografía que abre el libro, donde se muestra el cuerpo desnudo de una mujer que abraza un huevo gigante. Esta misma imagen, a su vez, reverbera en muchos de los enunciados poemáticos de Ugalde, sobre todo, en aquellos donde la poeta se auto-retrata en el momento de la experiencia estética que precede a la creación misma:

\author{
Un huevo invisible, en nuestro interior \\ contiene la electricidad del universo \\ la euforia del primer estallido \\ su cáscara es frágil y poderosa \\ como el brillo del escarabajo \\ y el calor que nos damos \\ y el silencio de las carreteras. ${ }^{41}$
}

39 La artista visual Gema Polanco (Valencia, 1992) es Licenciada en Fotografía por el London College of Communication (2015) y MA en Artes Visuales y Educación por la Universidad de Barcelona (2017). Su obra fotográfica ha sido expuesta en numerosas muestras europeas y ha recibido varias distinciones. Las fotos que se incluyen en el poemario se tomaron en Londres y fueron seleccionadas por la poeta para trabajarlas en diálogo con sus propios textos. (Comunicación personal de Begoña Ugalde). Cfr: http://panoramicgranollers.cat/es/portfolio/lt-gema-polanco/ [Consultado el 25 de abril 2020].

40 Alicia Salomone: «Identidad femenina, poética y política en La fiesta vacía de Begoña Ugalde y Gema Polanco». In: Aisthesis: Revista Chilena de Investigaciones Estéticas 66 (2019), p. 239.

41 Begoña Ugalde: La fiesta, p. 119. 
En otros casos, las imágenes de Polanco incorporan frases callejeras en inglés, reunidas por ella en sus recorridos por la ciudad de Londres. Junto con metonimizar la condición transcultural de la poesía de Ugalde, ellas producen un reenvío hacia la indagación de la hablante en torno del lenguaje, el sentido y el poder crítico de la palabra poética. Es el nexo que puede establecerse, por ejemplo, entre la imagen cortada de un grafiti rescatado por Polanco: «If only the words had meaning» ${ }^{42}$ [«si acaso las palabras tuvieran algún significado», mi traducción] o la interpelación inquietante que se lanza desde un afiche con diseño comercial: «have you sold your soul?» ${ }^{43}$ [ « ¿has vendido tu alma?», mi traducción], y las reflexiones que asoman en el poema de Ugalde. En algunos casos, son dilemas que surgen de su proceso introspectivo:
No es lo mismo enunciar la duda
que guardar silencio, junto a los recibos
las fotos, las postales de otros viajes
cavar un hoyo en la arena y quemarlo todo
ensayar en soledad
pequeñas catástrofes naturales. ${ }^{44}$

En otras ocasiones, son interrogantes que se emergen en el vínculo dialógico con otros:

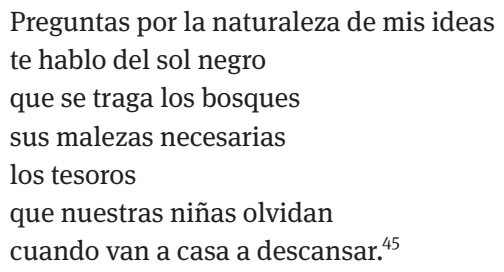

Finalmente, otra de las imágenes de Polanco, un cisne blanco desplazándose por un lago, que ocupa una doble página casi en el centro del poemario, también es recogida en varios versos de Ugalde. Para el/la lector/a hispanoamericano/a, esta imagen inmediatamente sugiere una relación con la estética modernista y su discursividad metapoética, tal como fue asentada magistralmente por Rubén Darío en «Yo persigo una forma. . .» y otros poemas ${ }^{46}$ Sin embargo, mientras el poema

\footnotetext{
42 Ibid., p. 11.

43 Ibid., p. 18-19.

44 Ibid., p. 93.

45 Ibid., p. 100.

46 «Yo persigo una forma que no encuentra mi estilo, / botón de pensamiento que busca ser la rosa; [...] Y no hallo sino la palabra que huye [.. .] y bajo la ventana de mi Bella-Durmiente, el sollozo continuo del chorro de la fuente y el cuello del gran cisne blanco que me interroga» (Rubén
} 
dariano se preguntaba frente al cisne acerca de la forma perfecta de la poesía, más próximo al cisne agustiniano ${ }^{47}$ que incorpora el rastro rojo de la corporalidad femenina, ${ }^{48}$ el cisne ugaldiano enuncia desde una subjetividad lírica en tensión extrema, llamándose a sí misma «cisne y furia desatada». ${ }^{49} \mathrm{Si}$ bien Ugalde no se desentiende en lo absoluto de la preocupación por la forma, su pregunta por el sentido de la poesía aparece atravesada por una inquietud ético-política. Es más, pensando en un mundo que se encuentra ad portas de una catástrofe ecológica que podría poner fin a la vida en el planeta, su interrogación en torno de la forma adopta el tono de un clamor angustioso: «¿Cómo podría ser todo de otra forma?»:
¿Cómo hacer de la asfixia una costumbre?
¿Quiénes sobrevivirán a esta dilatación?
¿Dónde se ocultarán los animales blancos?
¿Cómo podría ser todo de otra forma? ${ }^{50}$

Esa voz profética, que ya se había anunciado en los Poemas sobre mi normalidad, vuelve a despuntar en estos versos de La fiesta vacía. Sin embargo, si en el primer libro la reflexión de la hablante se plegaba sobre sí misma, como buscando dibujar un territorio propio dentro del entramado de afectos familiares, en el segundo poemario, ella procura la compañía de unas otras, como si no se quisiera sola en el empeño de crear nuevas y mejores formas de existencia. Por esta vía, el cisne furioso de Ugalde muta, nuevamente, hasta tomar la forma de una maga o una bruja y, enunciando desde ese personaje, invoca las fuerzas de la tierra y el deseo. Desde allí, también convoca a sus hermanas, que son, como ella, figuras femeninas disidentes, y las suma a la tarea de imaginar un nuevo mundo, desde la transición del yo hacia un sujeto femenino colectivo: «Yo / Tú / Nosotras»:

\author{
Por eso escribo \\ Nosotras \\ Yo \\ Tú \\ Nosotras. ${ }^{51}$
}

Darío: Del símbolo a la realidad. Obra selecta. Madrid: Real Academia Española y Asociación de Academias de la lengua española 2016, p. 83).

47 «Yo soy el cisne errante de los sangrientos rastros / voy manchando los lagos y remontando el vuelo» (Delmira Agustini: Poesías completas. Madrid: Cátedra 1993, p. 254).

48 Sylvia Molloy: «Dos lecturas del cisne: Rubén Darío y Delmira Agustini». In: Patricia Elena González y Eliana Ortega (eds.): La sartén por el mango. Puerto Rico: Huracán 1984.

49 Begoña Ugalde y Gema Polanco: La fiesta, p. 87.

50 Ibid., p. 79.

51 Ibid., p. 95. 
El recorrido autorreflexivo de la hablante por una ciudad cuyo ánimo celebratorio no comprende ni comparte, termina por configurar otros sentidos y sellar nuevas alianzas, lo que, a su vez, provoca en ella el estallido de una euforia de tipo diferente. Así, frente a la fiesta vacía, brota en ella un entusiasmo de tono colectivo y feminista, que le permite idear - en y a través de la poesía - un habitar diverso y libertario por el que, incluso, está dispuesta a correr todos los riesgos:

Todos los paraísos conviven adentro

hablamos con múltiples acentos

el idioma salvaje del orgasmo

aferradas las unas a las otras

nos arrojamos seguras

de atravesar la barrera del sonido..$^{52}$

\section{Conclusiones}

La poética de Ugalde se inscribe en las coordenadas del espacio poético de mujeres chilenas que se configura en los 2000, en un contexto sociocultural donde se hacen audibles las voces de nuevos actores sociales, entre los cuales destacan los movimientos feministas. En este escenario, se hace visible un sólido campo poético de mujeres que, con el respaldo que le brinda una trayectoria de décadas, se constituye como un agente relevante en el mapa literario y cultural del Chile contemporáneo. Dentro de esta geografía poética me interesó iluminar la zona constituida por sujetos femeninos que, desde un posicionamiento extramuros, crean una poesía que traspasa fronteras territoriales, culturales y lingüísticas para mirar críticamente las identidades y las subjetividades, así como las materialidades, condiciones y finalidades de la praxis poética.

Los dos últimos poemarios de Begoña Ugalde pueden ser leídos desde esa cartografía, como exploraciones profundas en una subjetividad poética que se recrea a sí misma a través de la poesía al tiempo que ausculta a esta en sus recursos, procedimientos y potencialidades estético-políticas. En Poemas de mi normalidad, la hablante lírica se autorrepresenta ficcionalmente en el espacio privado, buscando allí las raíces de una identidad literaria que ha construido a lo largo del tiempo pero que arraiga en una dilatada tradición familiar. No obstante, lejos de quedar presa de esa trama íntima, ella desarticula la dicotomía público/privado evidenciándola como un continuum que alimenta una praxis poética que, a la

52 Ibid., p. 126-127. 
vez, es política. De esta forma, si, para la hablante, el espacio del hogar necesariamente conlleva el peso de lo rutinario y la dificultad de lidiar con los vínculos próximos; por otra parte, puede ser un estímulo y fuente esencial para la creación poética y la reflexión crítica, deconstruyendo la idea de que lo privado solo representa la carencia y la alienación del sujeto femenino.

Por su parte, en La fiesta vacía, lo público y urbano, epítome por excelencia de la expresión y circulación del sujeto poético moderno, puede operar en un sentido inverso, adoptando la fisonomía de un espacio vacuo en el que las miserias se ocultan tras las luces del movimiento incesante. Sin embargo, como si quisiera encontrar un sentido provechoso a sus propios recorridos, la hablante lírica reconstruye la ciudad desde nuevos itinerarios. Y esto lo lleva a cabo desde una lucidez autoconsciente que procura, además, los lenguajes adecuados para acoger ese tipo de experiencia. En el proceso de transformación por el que atraviesa la hablante a lo largo del poemario, un elemento crucial es la conexión intermedial entre palabra poética e imagen fotográfica, que viabiliza una reflexión metapoética desde la contraposición entre esas dos materialidades significantes. Es mediante ese diálogo, precisamente, como la subjetividad lírica produce su propia recreación, haciendo confluir imagen y palabra para dar curso a su vocación estética y, también, a su deseo de imaginar nuevas convivencias: un habitar menos depredador del sí mismo y de los otros, así como del planeta que debiera ser el digno hogar de todos. La figura apacible del cisne en el centro del poemario, que contiene la palabra furiosa de esa misma figura ante un modo de vida crecientemente insano, sintetiza magistralmente la tensión que atraviesa, como un motor productivo, la lírica de Begoña Ugalde, definiendo una poética que ella misma nombra bellamente como «cisne y furia desatada». ${ }^{53}$

\section{Bibliografía}

Agustini, Delmira: Poesías completas, ed. de Magdalena García Pinto. Madrid: Cátedra 1993.

Bortignon, Martina: «Fotos y voces en la ciudad. La marginalidad en la poesía chilena del 2000 desde una perspectiva intermedial». In: Literatura y Lingüística 22 (2015), p. 159-178.

Carnero, Guillermo: «Precedentes de la poesía social de la postguerra española en la anteguerra y guerra civil». In: Las armas abisinias: Ensayos sobre literatura y arte del siglo XX, p. 274-298. Barcelona: Anthropos 1989.

Company, Flavia: «Vivir desde lugar propio y ajeno». In: Begoña Ugalde: Poemas sobre mi normalidad, p. 7-8. Santiago: Aerea-Carménère 2018.

53 Ibid., p. 87. 
Darío, Rubén: Del símbolo a la realidad. Obra selecta. Madrid: Real Academia Española y Asociación de Academias de la lengua española 2016.

Falabella, Soledad, Graciela Huinao y Roxana Miranda Rupailaf (eds.): Hilando en la memoria. Epu rupa. 14 mujeres mapuche. Santiago de Chile: Cuarto Propio 2009.

Faúndez, Edson: «Geografía de la nada. La poesía de Malú Urriola». In: Taller de Letras 54 (2014), p. 39-56.

Fernández Melleda, Bárbara: Neoliberalism and its Discontents. Three Decades of Chilean Women's Poetry [PhD Dissertation]. Edimburgo: The University of Edinburgh 2019. https://era.ed.ac.uk/bitstream/handle/1842/35852/Fernandez2019.pdf?sequence=1\& isAllowed=y [Consultado el 25 de abril 2020].

Hernández, Elvira: Los trabajos y los días. Antología. Santiago de Chile: Lumen 2016.

-: «Contemporaneidad de la poesía escrita por mujeres en la poesía chilena». In: Simpson. Sociedad de Escritores de Chile 7 (1992), p. 109-111.

http://www.memoriachilena.gob.cl/602/w3-article-83307.html [Consultado el 28 de abril 2020].

Lucifora, María Clara: «Las autopoéticas como máscaras». In: RECIAL: Revista del Centro de Investigaciones de la Facultad de Filosofía y Humanidades, Áreas Letras 11 (2017), s. p. https://dialnet.unirioja.es/revista/23617/V/8 [Consultado el 25 de junio 2020].

Luongo, Gilda: «Guerra Florida de Daniela Catrileo: «Perfume fragante de la memoriamadreselva〉 0 <esta danza es por nosotras »). In: Biblioteca fragmentada (2019). http://www.bibliotecafragmentada.org/guerra-florida-de-daniela-catrileo/ [Consultado el 25 de junio 2020].

Marchant Rivera, Julieta: El ser o su intermedio: el desmontaje del yo en la poesía de Nadia Prado [Tesis para optar al grado de Magíster en Literatura]. Santiago de Chile: Universidad de Chile 2013. http://repositorio.uchile.cl/handle/2250/115168 [Consultado el 25 de junio 2020].

Molloy, Sylvia: «Dos lecturas del cisne: Rubén Darío y Delmira Agustini». In: Patricia Elena González y Eliana Ortega (eds.): La sartén por el mango, p. 57-69. Puerto Rico: Huracán 1984.

Mora Curriao, Maribel y Fernanda Moraga (eds.): Kümedungun/Kümewirin. Antología poética de mujeres mapuche (siglos XX-XXI), versión mapudungun Jacqueline Caniguán. Santiago de Chile: LOM 2010.

Moraga, Fernanda: «Catabática: cartografía de subjetividades fronterizas». In: Literatura y Lingüística 26 (2012), p. 47-59.

Nómez, Naín: «Poesía de mujeres en Chile: Voces del simulacro entre la dictadura y la transición». In: Milena Rodríguez Gutiérrez (ed.): Casa en la que nunca he sido extraña. Las poetas hispanoamericanas: identidades, feminismos, poéticas (Siglos XIX-XXI), p. 91-102. New York: Peter Lang 2017.

Pérez Bowie, José Antonio: «Para una tipología de los procedimientos metaficcionales en la lírica contemporánea». In: Tropelías 3 (1992), p. 91-104.

-: «Sobre lírica y autorreferencia (algunos ejemplos de la poesía española contemporánea)». In: J. M. Pérez Gago (ed.): Semiótica y modernidad II, p. 237-247. A Coruña: Universidad de A Coruña 1994.

Real Academia Española: Diccionario de la lengua española. https://dle.rae.es/.

Salomone, Alicia: «Identidad femenina, poética y política en La fiesta vacía de Begoña Ugalde y Gema Polanco». In: Aisthesis: Revista Chilena de Investigaciones Estéticas 66 (2019), p. 237-239. 
Sánchez Torre, Leopoldo: La poesía en el espejo del poema. La práctica metapoética en la poesía española del siglo XX. Oviedo: Universidad de Oviedo 1993.

Scarano, Laura: «Escribo que escribo: de la metapoesía a las autopoéticas». In: Tropelías: Revista de Teoría de la Literatura y Literatura Comparada 2 (2017), p. 133-152.

-: «Poesía y nombre de autor: entre el imaginario autobiográfico y la autoficción». In: CELEHIS: Revista del Centro de Letras Hispanoamericanas 22 (2011), p. 219-239.

Sepúlveda, Magda: «El territorio y el testigo en la poesía chilena de la Transición». In: Estudios filológicos 45 (2010), p. 79-92.

Ugalde, Begoña: Poemas sobre mi normalidad. Santiago de Chile: RIL Editores/ Aerea-Carménère 2018.

Ugalde, Begoña y Gema Polanco: La fiesta vacía. Barcelona: TEJE 2019.

Vattimo, Gianni: Poesía y ontología. Valencia: Universidad de Valencia 1993.

Zonana, Víctor: Poéticas de autor en la literatura argentina (desde 1950), vol I. Buenos Aires:

Corregidor 2007. 